\title{
有機污濁が進む閉鎖性水域の嫌気的・還元的条件下での水質動態
}

\author{
原田昌佳 1 平松和昭 $2 \cdot$ 福田信二 3
}

\section{Dynamics of Water Qualities under the Anaerobic and Reductive State in an Organically Polluted Closed Water Body}

\author{
Masayoshi Harada $^{1}$, Kazuaki Hiramatsu ${ }^{2}$ and Shinji Fukuda ${ }^{3}$
}

\begin{abstract}
It is essential to study the mechanisms of the decomposition of anaerobic organic matter such as denitrification, iron reduction and sulfate reduction caused by oxygen depletion when considering the conservation and restoration of a closed water area under organic contamination. In this study, we observed the water quality of a reservoir with significant organic contamination due to humic acid, and evaluated quantitatively the water quality changes over time with respect to the oxidation reduction potential (ORP) as well as sulfides, ammonium nitrogen $\left(\mathrm{NH}_{4}{ }^{+}-\mathrm{N}\right)$, phosphate-phosphorus $\left(\mathrm{PO}_{4}^{3-}-\mathrm{P}\right)$, and sulfate ions $\left(\mathrm{SO}_{4}{ }^{2-}\right)$ during an anoxic period. The study showed that the changes of the ORP under anaerobic conditions can be modeled using a logistic regression based on the number of consecutive anoxic days. It was suggested that the higher the initial concentration of nitrate nitrogen was, the smaller declining rate of the ORP was from an oxidized state to a reductive state. Furthermore, it was shown that the increase of $\mathrm{NH}_{4}{ }^{+}-\mathrm{N}, \mathrm{PO}_{4}{ }^{3-}-\mathrm{P}$, and sulfides over time, as well as the reduction of $\mathrm{SO}_{4}{ }^{2-}$, can be evaluated using a linear regression based on the number of days elapsed in which both an ORP level of less than $-200 \mathrm{mV}$ and a dissolved oxygen level of $0 \mathrm{mg} / \mathrm{l}$ are sustained. The dynamics of inorganic nitrogen, phosphorus, and sulfur compounds can be estimated and predicted using the two above-mentioned regression models without any mathematical model on the complex biochemical processes. This is valid information for the analysis of aquatic environments, which can contribute to the conservation and sustainable management of closed water areas.
\end{abstract}

Keywords: Anoxic water; Dissolved oxygen; Oxidation-reduction potential; Sulfide; Nutrient salt

\section{1 はじめに}

有機污濁が進む閉鎖性水域で憂慮するべき水環境問題 は水域の貧酸素化·無酸素化である.これは, 多量な懸濁 態·溶存態物質に因る寡少な水中光環境が無光層や水温. 成層を形成する結果として生じる現象であり, 水生生物の 酸欠死, 栄養塩類の溶出, 硫化水素・メタンガスの発生, 底質のへドロ化などの更なる水環境の劣化に繋がる(有田, 1998; 永田ら, 2012; 山室ら，2013）。これらの有機污濁現 象の多くは, 水域の嫌気的条件下で起こりうる生物化学的 反応に起因し, 例えば, 鉄還元に伴うリン酸の溶出は富栄 養化の加速の原因 (武田, 2001), また硫酸還元による硫 化水素の発生はその毒性により水圈生態系へのダメージ の直接的な原因 (中村ら, 1997) となる. そのため,このよう な閉鎖性水域の水環境の保全・修復を考える上で, 流域 からの水質污濁物質の流入負荷特性を把握寸るだけでな く, 水域内部での生物化学的な物質循環を踏まえた水質 動態を定量的に理解することは必要不可欠である. とくに, 無酸素化を要因と寸る脱窒, 鉄還元, 硫酸還元などの嫌 気的有機物分解の発生メカニズムの定量的評価は重要な 課題の一つといえる.

\section{好気性微生物による有機物分解によって溶存酸素}

1 九州大学大学院農学研究院准教授 Associate Professor, Faculty of Agriculture, Kyushu University, 6-10-1 Hakozaki, Higashi-ku, Fukuoka 812-8581, Japan (Corresponding Author) E-mail: mharada@bpes.kyushu-u.ac.jp

2 九州大学大学院農学研究院教授 Professor, Faculty of Agriculture, Kyushu University, 6-10-1 Hakozaki, Higashi-ku, Fukuoka 812-8581, Japan

3 東京農工大学農学研究院助教 Assistant Professor, Faculty of Agriculture, Tokyo University of Agriculture and Technology, 3-5-8 Saiwai-cho, Fuchu-shi, Tokyo 183-8509, Japan
(DO)が減少し, 貧酸素化が進行すると, 酸素を含む化合 物を利用した還元半反応が, 酸化還元電位(ORP)の高い ものから低いものへと順に起こる. 主な反応を電位の高い 順に挙げると, 二酸化マンガンの還元, 脱窒と硝酸還元, 鉄水和物の還元, 硫酸還元, 硫黄還元, メタン発酵, 窒素 固定などである(寒川・日色，1996）。理論的には，水環境 においてORPが測定されていれば, どの段階での還元半 反応が起きているのかを知ることができる。しかしながら， 実際の水域では, 様々な微生物を介した反応を背景に, 不特定多数の酸化還元反応が存在し, その反応系が明 確でない. さらに, 酸化還元状態の強度の尺度であるORP に関して, 実水域レベルでの定量的な評価方法に関する 知見も少ない. 例えば, 武藤・金(1986)は複数の河川を対 象に温度, $\mathrm{pH}, \mathrm{DO}, \mathrm{H}_{2} \mathrm{~S}, \mathrm{COD}$ な゙の要因がORPに与え る影響について検討し，DOやCODに対する相関が高いこ とを示した. しかし，嫌気的環境下にある水域においてそ の影響を検討した研究は皆無であり, ORPの定量的評価 方法は提案されていないのが現状である.

本研究では, 有機污濁現象が顕在化する貯水池を対 象に水質モニタリングを行い, その結果に基づく回帰分析 の観点から, ORP, 硫化物, アンモニア態窒素, リン酸態リ ンを指標と寸る水質環境の動態について定量的に評価し た. まず, ORPについては, 多項目水質計によるDO, 水温, ORPなどの定点連続観測結果を用いて, 無酸素期間の ORPの経時変化を表す回帰曲線を見出した.つぎに, 硫 化物, アンモニア態窒素, リン酸態リンの鉛直分布の季節 変化に関する多点定期観測結果より, 嫌気的条件下での 
これらの動態特性について, ORPと関連付けて定量的に 評価した。

\section{2 対象水域と水質モニタリングの概要}

\section{1 対象水域の概要}

本研究で対象と寸る閉鎖性水域は, 森林域を伐採し, 現 在造成中の大学キャンパス内の貯水池であり, 水面積は 約 $13,800 \mathrm{~m}^{2}$, 常時満水位は $8 \mathrm{~m}$, 総貯水量は約 $63,000 \mathrm{~m}^{3}$ である. 渴水時に斜樋を通じた放水を行い，下流域に水 田や施設畑の灌溉用水を供給している. 降雨時には, 二 つのボックスカルバート製水路を通じて流域内の水が貯水 池に流入し, 洪水吐きより下流域一と水が流出する. 造成 時に貯水池周辺の広範囲に渡って伐採木材チップが散 布され, そのチップ由来の大量の腐植酸が, 暗渠を通じて 雨水とともに同貯水池に流れ込んでいる. そのため, 対象 池は茶褐色を呈し, 透明度は夏季で $0.5 \mathrm{~m}$ 程度, 秋季で $1.0 \mathrm{~m}$ 程度と著しく低いこと, また夏季の水温成層の形成時 期では水深方向の広範囲に渡り無酸素状態であること,さ らに底質がへドロ化していることなど, 有機污濁の顕在化 が報告されている(原田ら, 2009; 吉村ら, 2010).

本研究では, このような貯水池の中心部の一地点におい て, 2012年に水質モニタリングとして多点定期観測および 定点連続観測を実施した。同年では, 下流域一の灌泊水 の供給を目的とした放水が5月に行なわれ，水位が $2 \mathrm{~m}$ 程 度低下したが，6月中旬の大雨で水位は常時満水位の約 $8 \mathrm{~m}$ まで回復した. そこで, 下記の水質モニタリングを 2012 年6月中旬に開始し，同年11月までの約5ケ月間実施した。 なお, 観測期間中に放水による水位の低下はなく, 観測ポ イントである貯水池中心部の水深は約 $8 \mathrm{~m}$ であった.

\section{2 水質モニタリングの概要}

多点定期観測では，6月中旬〜 11月に約 1 週間間隔で水 質の鉛直分布を測定した. まず, 現地にて多項目水質計 (Model6920, YSI/Nanotech社製) による水温, DO, pH, ORP, 電気伝導 $(E C)$ の測定を $0.5 \mathrm{~m}$ 間隔で行なった. また, 水中光量子計 (Compact-LW, JFEアドバンテック株式社 製)により光合成有効光量子密度 (光量子量)を $0.2 \mathrm{~m}$ 間隔 で測定した. さらに, 水面・水底近傍も含めて採水を $1 \mathrm{~m}$ 間 隔で行い, 試料水をクロロフィルa, 全窒素, 全少ン, 全有 機炭素(TOC), 溶存態有機炭素(DOC), アンモニア態窒 素 $\left(\mathrm{NH}_{4}{ }^{-}-\mathrm{N}\right)$, 硝酸態窒素 $\left(\mathrm{NO}_{3}{ }^{-}-\mathrm{N}\right)$, リン酸態リン $\left(\mathrm{PO}_{4}{ }^{3-}-\mathrm{P}\right)$, 硫酸イオン $\left(\mathrm{SO}_{4}{ }^{2-}\right)$, 硫化物の計10項目の水質 分析に供した. ここで, 硫化物は硫化水素, 硫化水素イオ ン, 硫化物イオンの総称である. 本研究の主要な水質項 目の分析方法は次の通りである.まず, 有機炭素量の測 定には, 湿式紫外線酸化一ガス透過膜式導電率測定方 式のTOC分析計を使用した. また, $\mathrm{NO}_{3}{ }^{-}, \mathrm{PO}_{4}{ }^{3-}, \mathrm{SO}_{4}{ }^{2-}$ の アニオン分析ではイオンクロマトグラフ法を採用した. さら に， $\mathrm{NH}_{4}-\mathrm{N}$ と硫化物ついてはそれぞれネスラー法, メ于 レンブルー法に基づき, 分光光度計を用いて分析した. 一 般に, 硫化物や硫酸イオンは有機污濁・富栄養化関連項 目に含まれない.しかしながら, 水温躍層が形成される夏 季に, 深水層に該当する水深範囲での硫化水素の発生 がその特有の臭気により確認された. 対象池において無 酸素化に起因する硫酸還元が起こりうるとの判断から, $\mathrm{SO}_{4}{ }^{2-}$ と硫化物を室内分析項目として加えた.

定点連続観測は, 夏季の水温成層の形成・発達に起因
するDOの低下によって嫌気的状態に転じてから, 秋季の 鉛直混合に伴って無酸素化が解消されるまでの期間を対 象に, 短い時間間隔でORPの変動特性を調べるために実 施したものである. 6月中旬以降の貯水池の水位が常時満 水位に達した時点で, $6 \mathrm{~m}$ 以深で貧酸素化・無酸素化が進 み, 水底近傍はすでに還元的状態であった. そのため, 水深 $5 \mathrm{~m}$ を観測点としてこの位置に上述と同様の多項目水 質計を固定し, 水温, DO, pH, ORP, ECの連続観測を20 分間隔で行なった。同水質計では蛍光式DO電極が用い られていることから, DO測定の応答性が速く, 測定精度や 再現性も優れている. また, 付着物防止のためのワイパー が搭載されていることから, 安定した定点連続観測の実施 が可能である. また, ORPは測定電極を白金, 比較電極を 塩化銀とするセンサで測定されたものであり, 水素標準電 極による電位(Eh)への換算はしていない. なお, 測定值に 200mVを加えることでEhのおおよその值を知ることができ る. 本水質計では圧力式水深センサによる水深データも 合わせて集録されており, 同データから, 観測期間中の水 質計はほぼ水深 $5 \mathrm{~m} の$ 位置に固定されたことを確認した。

\section{3 結果と考察}

\section{1 水質鉛直分布の季節変化}

多点定期観測結果の一例として, 図 1に各月の代表的な 水中光量子量, 水温, DO, ORP, DOC, DOC/TOC比, $\mathrm{NH}_{4}{ }^{+}-\mathrm{N}, \mathrm{NO}_{3}{ }^{-}-\mathrm{N}, \mathrm{PO}_{4}{ }^{3-}-\mathrm{P}, \mathrm{SO}_{4}{ }^{2-}$, 硫化物の鉛直分布を 示し, 同図を通じて対象池の特徵をまとめる. 図中の水中 光量子量は水面の測定値で $[0,1]$ に基準化した值である.
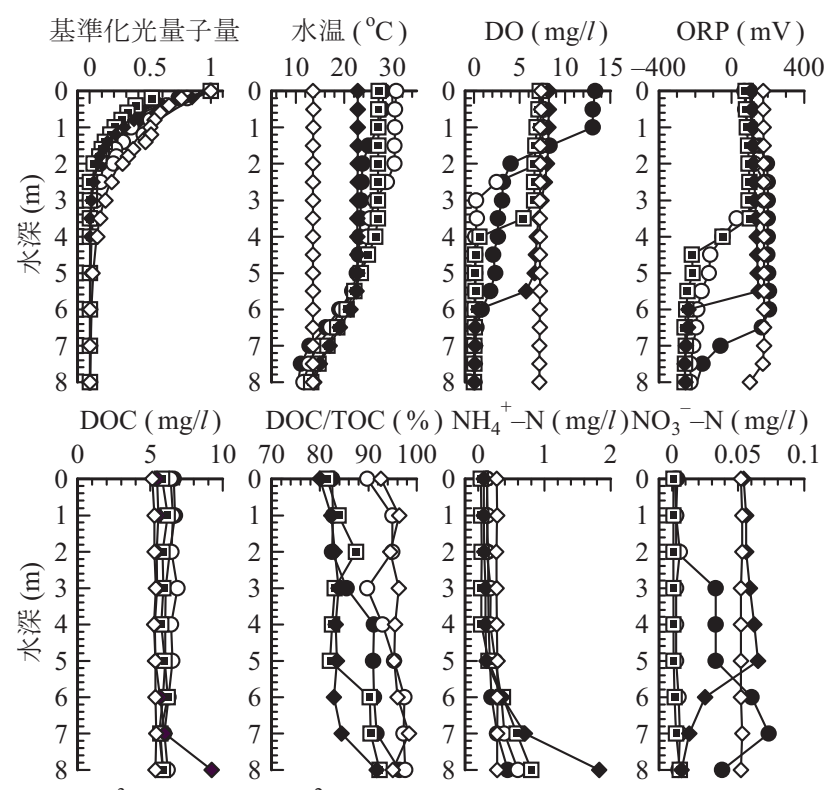

$\mathrm{PO}_{4}{ }^{3-}-\mathrm{P}(\mathrm{mg} / \mathrm{l}) \quad \mathrm{SO}_{4}{ }^{2-}(\mathrm{mg} / \mathrm{l})$ 硫化物 $(\mathrm{mg} / l)$

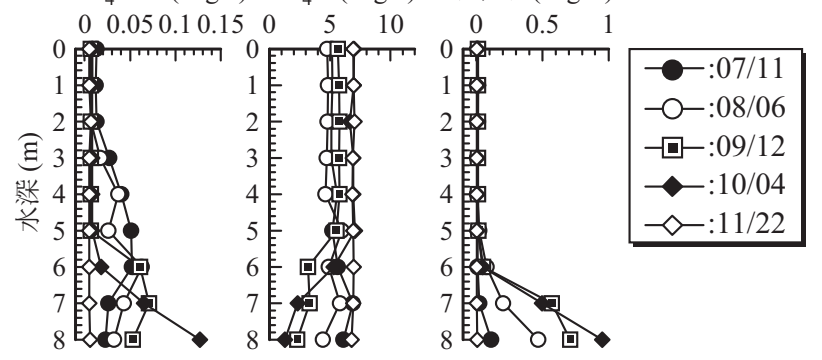

図 1: 多点定期観測結果の一例 
まず, 水中光量子量の測定結果によれば, 光強度がゼ 口に転じる水深は観測期間を通じて 2 3mの範囲にあり, 水中光環境の鉛直分布特性の季節変化は小さい. DOC は水深方向に一様な分布を示し, 季節的変動もほとんど 見られない. 一般に湖水中のDOCのTOCに対する存在比 は40\%程度との報告があるが(今井, 2004), 対象池では 80～90\%と極めて高いことから, 腐植酸の流入負荷の影響 を強く受けていることが分かる. また, 腐植酸の難分解性 により, 水中光の減衰の主要因であるDOCの水深や季節 に対する変化は小さく, この結果として, 基準化光量子量 の鉛直分布は季節の影響を受けないと考えられる.

このような寡少な水中光環境の影響を受けて, 7月以降 に水温2成層が形成された. 8 月に, 表層部 (混合層)が水 面から $2 \mathrm{~m}$ 程度と浅く, また水面と水底の水温差が約 $20^{\circ} \mathrm{C}$ と 非常に大きいなど，強固な水温成層の発達を確認できた。 10月以降に, 放射冷却に伴う水面温度の低下によって鉛 直混合が顕著となり，11月下旬には水温成層は消滅した。 DOやORPの鉛直分布は, 以上の水温成層の形成・発達・ 消滅の過程と連動するような季節変化を示した. すなわち, 強固な成層が形成された 8 月では約 $2 \mathrm{~m}$ 以深で無酸素状 態にあり, 9月以降, 無酸素化に転じる位置が徐々に下が り，11月の水温成層の消滅によってDOは一様分布を示し た. 一方, 無酸素化に伴う還元的状態は $4 \mathrm{~m}$ 以深で確認さ れ，水底近傍に限定されることなくORPは-200mV程度ま で低下した。ORPが負に転じる位置は, 強固な水温成層 が形成される 8 月で水深 $3.5 \mathrm{~m}$ と最も浅く, 9 月下旬以降の 混合層の発達と共に水底へと降下した。

窒素, リン, 硫黄の無機化合物イオンについては, 4m以 深で季節的な変化が顕著であった. 7月〜10月の期間で $\mathrm{PO}_{4}{ }^{3-}-\mathrm{P}, \mathrm{NH}_{4}{ }^{+}-\mathrm{N}$, 硫化物の各濃度は増加し, 一方, $\mathrm{SO}_{4}{ }^{2-}$ は減少した. DOの鉛直分布の季節変化と併せると, これらの濃度変化は水域が無酸素状態に至ってからの経 過時間と関係し, 継続的な嫌気的状態が窒素, リン, 硫黄 を指標とする水質環境に及ぼす影響の大きさを確認でき

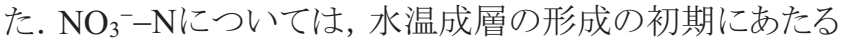
7月では水深が深いほど濃度が高く, 8月, 9月の嫌気的・ 還元的状態下で濃度はゼロへと減少した。10月，11月で は, 鉛直混合の発達により, 他の水質項目と同様, 水深方 向に一様な分布を示した. なお, 水底近傍を除く水深全 域で好気的状態にあった6月20日の観測結果によれば, 水深 $5 \mathrm{~m}, 6 \mathrm{~m}, 7 \mathrm{~m}$ の順で $\mathrm{NO}_{3}{ }^{-}-\mathrm{N}$ は $0.018 \mathrm{mg} / l, 0.125 \mathrm{mg} / l$, $0.245 \mathrm{mg} / l$ であった. 7 月の観測結果も踏まえると, 成層化 前ならびに成層化初期の段階では, 水深のより深い位置 でNO${ }_{3}^{-}-\mathrm{N} は$ 高濃度を示した。

\section{2 嫌気的条件下でのORPの経時変化}

一般に, 酸化還元反応の平衡式では, 酸化物質濃度 $[\mathrm{Ox}]$, 還元物質濃度 [Red], 酸化還元電位 Eh の関係は 次式で表される(寒川・日色，1996）。

$$
\mathrm{Eh}=\mathrm{E}_{0}+\frac{R T}{n F} \ln \frac{[\mathrm{Ox}]}{[\mathrm{Red}]}+\frac{R T}{F} \ln \left[\mathrm{H}^{+}\right]
$$

ここで， $\mathrm{E}_{0}$ は基準電位， $R$ は気体定数， $T$ は絶対温度， $n$ は反応で授受される電子の数, $F$ はFaraday 定数, $\left[\mathrm{H}^{+}\right]$は水素イオン濃度である. 例として, 表 1 に酸素分圧 $0.21 \mathrm{~atm}$, 水温 $25^{\circ} \mathrm{C}, \mathrm{pH} 7$ の水溶液条件における主要な還 元半反応のEhをまとめる(安部・半谷，1976). しかしなが ら, 微生物が媒介する場合, 数種の酸化還元反応が複合
して生じ, 複雑化するため, ORPに対する定量的関係は明 確でない.また, ORPは多様な要因の影響を受け, 直接的 なものとして温度, $\mathrm{pH}$, 対象物質自体の好気性・嫌気性レ ベル, 共存塩類の有無やその濃度などが挙げられる. しか しながら, 既述のとおり, 実水域において上記の要因と関 連づけてORPを定量的に評価するまでには至っていない のが現状であり, とくに嫌気的環境下でのORPに関して定 性的な推定ですら難しい.

本研究では, 図 2 に示寸水深 $5 \mathrm{~m}$ での定点連続観測結 果に基づき, 無酸素状態でのORPの経時変化を検討した. まず, 同図の観測結果は次のようにまとめられる. 観測開 始時のDOは約 $6 \mathrm{mg} / l$ であったが, その後, 水温成層の形 成に起因してDOは減少し, $\mathrm{DO}<2 \mathrm{mg} / \mathrm{l}$ の貧酸素状態を 経て，7月 25 日にDO $=0 \mathrm{mg} / /$ の無酸素状態に至った.この 間, DOの低下に伴うORPの変化は見られず, $200 \mathrm{mV}$ 前後 の一定值で推移した。無酸素化以後, ORPは速やかにか つ滑らかな曲線を描くように約 $-400 \mathrm{mV}$ まで低下し, $\mathrm{DO}=0 \mathrm{mg} / \mathrm{l}$ の期間では, この值で還元的状態を維持した. 水面冷却に起因する混合層の形成・発達が水深 $5 \mathrm{~m}$ の位 置にまで達した9月20日に, 水温と同様にDOも一様化した ことで無酸素化が解消されると, ORPは速やかに負から正 へと転じ, 酸化的状態に戻った。一方, 貧酸素・無酸素期 間中の水温, $\mathrm{pH}, \mathrm{EC}$ はおおよそ $23^{\circ} \mathrm{C}, 7.0,0.09 \mathrm{mS} / \mathrm{cm}$ の 一定值でそれぞれ推移した。 上述のとおりORPはDO, 水 温, $\mathrm{pH}, \mathrm{EC}$ と強い関連性を持つことが指摘されているもの の, 無酸素期間中のこれらの要因はほぼ一定の条件にあ った. そのため, 図 2 の水温・pH・ECが一定のもとでの ORP低下といら変化に対して, 生物化学的反応の温度や 酸・アルカリ性への依存性あるいは共存する塩類濃度が 及ぼす影響は極めて小さいと考えられる。

表 1: 水環境で起きうる主な酸化還元反応の Eh

\begin{tabular}{cllc}
\hline 反応名 & 酸化形 & 還元形 & $\mathrm{Eh}(\mathrm{mV})$ \\
\hline \hline 好気呼吸 & $\mathrm{O}_{2}$ & $\mathrm{H}_{2} \mathrm{O}$ & 760 \\
脱窒 & $\mathrm{NO}_{3}{ }^{-}$ & $\mathrm{N}_{2}$ & 740 \\
マンガン還元 & $\mathrm{MnO}_{2}$ & $\mathrm{Mn}^{2+}$ & 520 \\
硝酸還元 & $\mathrm{NO}_{3}{ }^{-}$ & $\mathrm{NH}_{4}^{+}$ & 360 \\
鉄還元 & $\mathrm{Fe}^{+}(\mathrm{OH})_{3}$ & $\mathrm{Fe}^{2+}$ & 130 \\
硫酸還元 & $\mathrm{SO}_{4}{ }^{2-}$ & $\mathrm{H}_{2} \mathrm{~S}$ & -180 \\
メタン発酵 & $\mathrm{CO}_{2}$ & $\mathrm{CH}_{4}$ & -240 \\
\hline
\end{tabular}
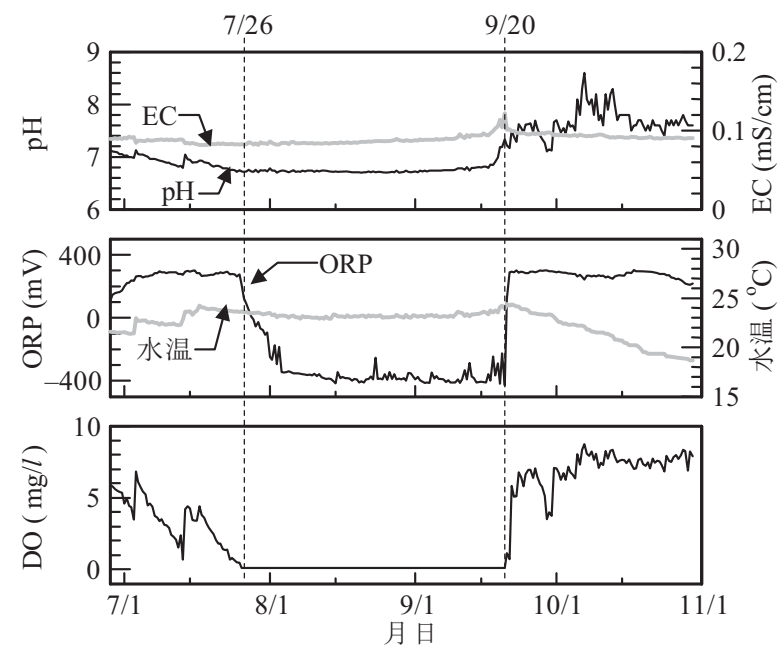

図 2: 水深 $5 \mathrm{~m}$ での定点連続観測結果 (2012 年) 

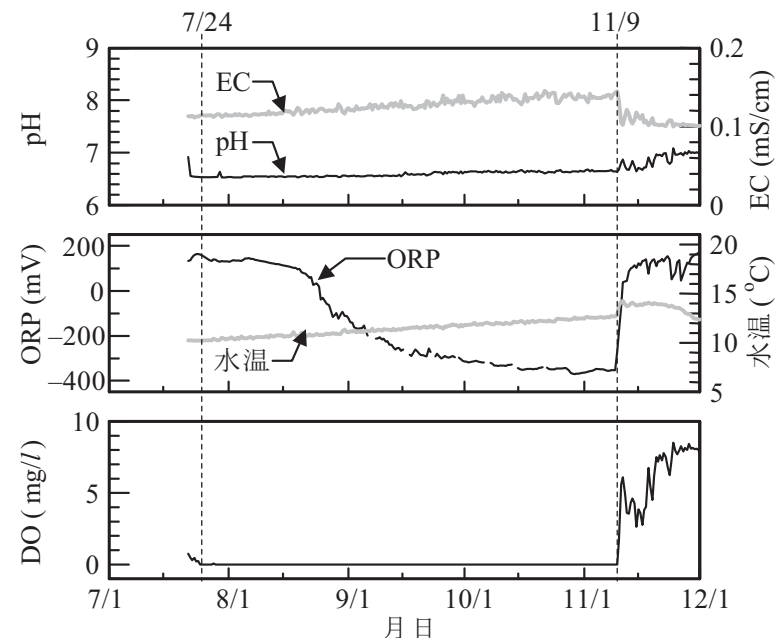

図 3: 水深 $7 \mathrm{~m}$ での定点連続観測結果 (2010 年)

ところで, 水温, DO, ORP, $\mathrm{pH}, \mathrm{EC}$ 関する同様な定 点連続観測を, 2010年7月〜11月に水深7mの位置にて行 い, 図 3の結果を得た。同年では, 観測開始時において $\mathrm{DO}=0.2 \mathrm{mg} /$ l と既に低濃度であり, 貧酸素化が進行してい た。 そのためDOの低下に対するORPの変化について明 確に把握できないものの, DO $=0 \mathrm{mg} / l$ 以後のORPは約 -400mVまで緩やかに低下し, 無酸素状態が解消されるま での期間, その值で推移した。この点で図 2の定点連続 観測結果と類似の結果を得た.また, 2012年と同様に, 無 酸素期間のpH, 水温, ECはほぼ一定で推移し,これらが ORPの低下に及ぼす影響は小さいといえる.

以上の2012年, 2010年の定点連続観測結果を踏まえて, 嫌気的条件下でのORPの動態は, 無酸素状態が継続した 日数 (以後, 無酸素継続日数) $t$ に強く依存すると仮定し た. また, ORPの経時変化を図 4に示す曲線でモデル化 し, このようなORPの低下を数学的に説明しうる関数として ロジスティック曲線に着目した. 好気的条件下でのORPの 一定值を $E_{\max }$, 嫌気的条件下でのORPの最下限值を $E_{\min }$ として, ORPの経時変化 $E(t)$ を次式で表す。

$$
E(t)=\frac{-\Delta E}{1+\exp \left(\alpha_{E}-\mu_{E} \cdot t\right)}+E_{\max }
$$

ここで， $\Delta E=E_{\max }-E_{\min }$ であり，明らかに正值をとる.また， $\alpha$ は初期值 $E(0)$ に関係するパラメータであり, $\mu_{E}$ はORP の正值加負值への低下速度, 寸なわち, 無酸素化によ って酸化的状態加還元的状態へと変化する速度を表す。 既述のとおり，無酸素状態に至った時点を $t=0$ とし, 2012 年では7月 25 日午後5時を, 2010年では7月 24 日午前3時 を時間軸の原点とした。ORPが低下し始めるまでの

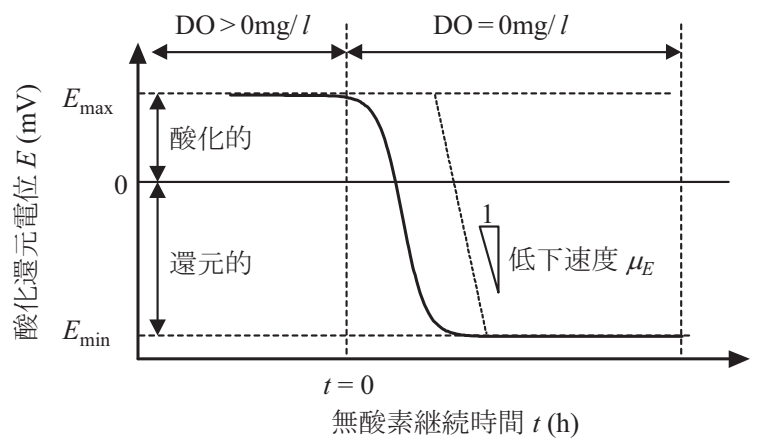

図 4: 嫌気的条件下での ORP 動態のモデル概念図
$\mathrm{DO}>0 \mathrm{mg} / \mathrm{ll}$ 対するORPの平均值をもつて $E_{\text {max }}$ を与えた 上で，最小2乗法により $\Delta E ， \alpha_{E}$ および $\mu_{E}$ を決定した. な お， $\mu_{E}$ は非線形項に含まれるため, 逐次計算によってこ れを求めた。計算結果を図 5,6に示す. 回帰曲線の精度 をNash-Sutcliffe係数(NS)で評価したところ，同図中に示 すように, 両年ともにNSが 0.9 を超え, 無酸素期間のORP の動態を式(2)によって良好にモデル化された.ここで, ORPの低下速度 $\mu$ (2012年: 0.530, 2010年: 0.098) に着 目すると, 水深によってその值は異なり, 水底に近いほど 酸化的状態から還元的状態への移行のスピードは遅いこ とが示唆された。

以上のとおり, 定点連続観測結果より無酸素状態での ORPの動態はロジスティック曲線に基づいた式(2)によって モデル化されることが明らかになった。 そこで, 多点定期 観測結果にも当てはめて, 式(2)中のパラメータについて 検討した. 対象データは2012年の多点定期観測結果のう ち, 無酸素化によってORPが正から負へ転じた $5 \mathrm{~m}, 6 \mathrm{~m}$,

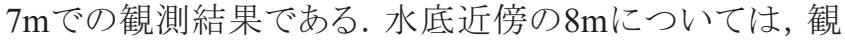
測開始時ですでに無酸素状態の還元的環境下にあり, $\mathrm{DO}=0 \mathrm{mg} / l$ となる日を基準とする無酸素継続日数を定め られないため, 同データは対象外とした。上記 3 点での ORPの観測結果に対するロジスティック曲線の近似結果を DOの経時変化と併せて図 7に示す. また, 同図中に, 無 酸素期間と判断した開始日と最終日の日付を記している. 約 1 週間間隔の定期観測であるため, 無酸素状態に至っ た時点 $t=0$ の判断に誤差はあるものの, 水深に関係なく, $\mathrm{NS}>0.9$ となる良好なORPの回帰曲線を得た。

つぎに，図 7中のモデルパラメータに着目した.まず,

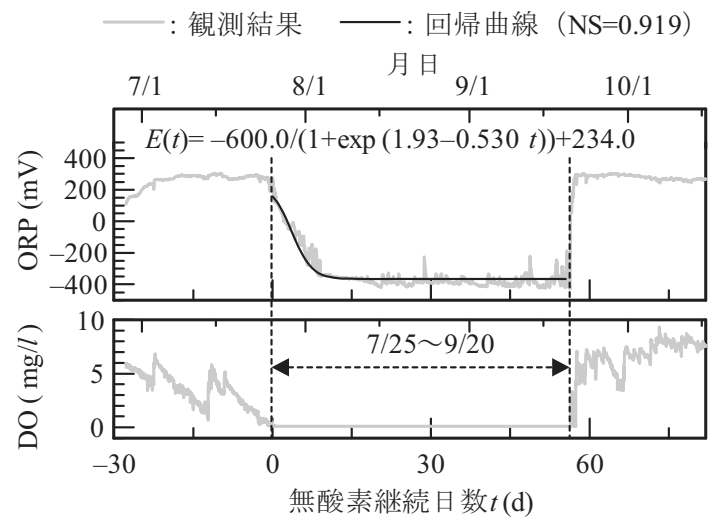

図 5: 2012 年定点連続観測結果に対する ORP の ロジスティツク曲線近似

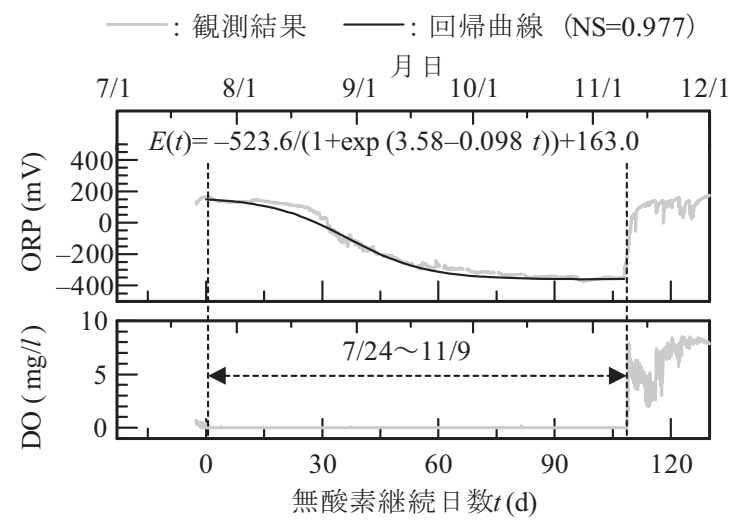

図 6: 2010 年定点連続観測結果に対する ORP の ロジステイック曲線近似 


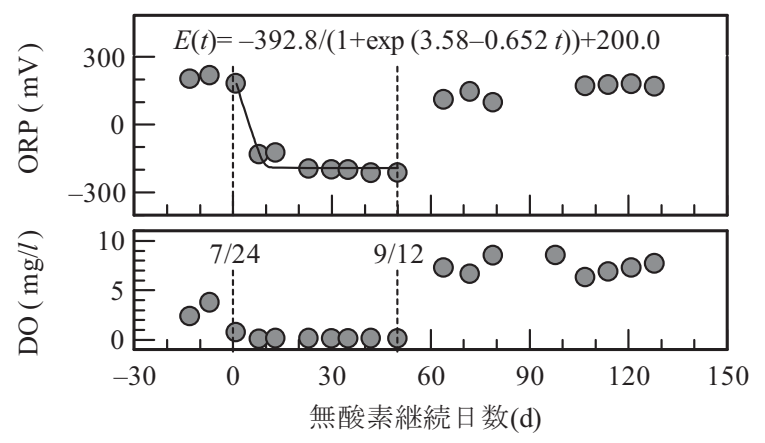

(1) 水深 $5 \mathrm{~m}(\mathrm{O}$ : 観測值, 一 : 回帰曲線, $\mathrm{NS}=0.975)$

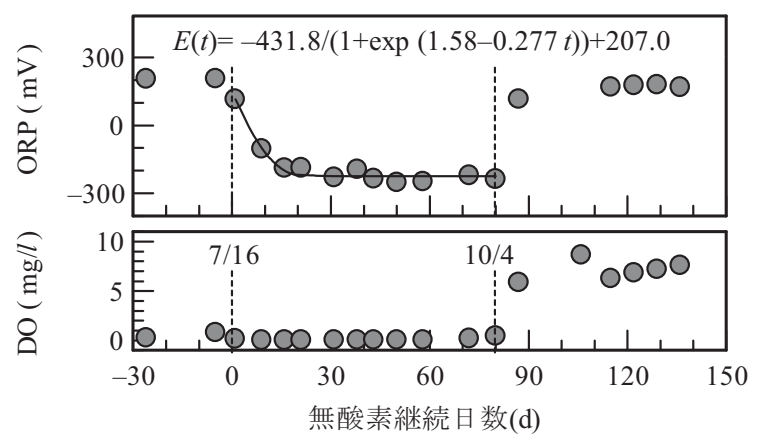

(2) 水深 $6 m （ O$ : 観測值, 一 : 回帰曲 線, NS=0.964)

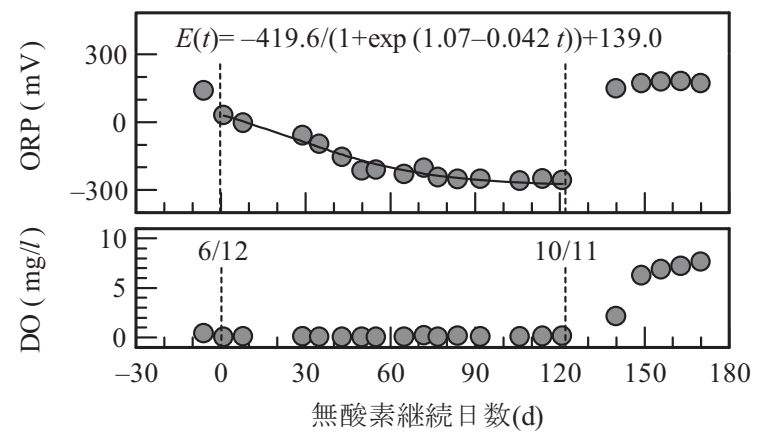

(3) 水深 $7 \mathrm{~m}(\mathrm{O}$ : 観測值, 一 : 回帰曲線, NS=0.929)

図 7: 2012 年多点定期観測データ $(5 \mathrm{~m}, 6 \mathrm{~m}, 7 \mathrm{~m})$

を用いた ORP のロジステイック曲線近似

嫌気的条件下でのORPの最下限值 $E_{\min }\left(=E_{\max }-\Delta E\right)$ は 水深 $5 \mathrm{~m}$ で-192.8mV, 6m で-224.8mV, また水深 $7 \mathrm{~m}$ で -280.6mVの值をとり, 水深が深いほど無酸素化による還 元的状態の強さは大きいことが分かる.これは, 底質に近 いほど硫酸還元などの電位の低い反応が活発化すること を反映した結果である.つぎに， $E_{\max }$ から $E_{\min }$ へのORPの 低下速度 $\mu_{E}$ に注目した。 図 7からも明らかなように, 水深 が深いほどその值は小さくなる。つまり, 水底近傍では ORPは緩やかに低下寸る一方で, 水底から離れるほよ゙, 無酸素化とともにORPは急激に低下した。このような相違 の要因として $\mathrm{NO}_{3}{ }^{-}$や $\mathrm{Fe}^{3+}$ の鉛直分布が挙げられる。一般 に, これらのイオン濃度が高いとき, 無酸素化後直ぐには 嫌気的有機物分解の最終段階である硫酸還元やメタン生 成には至らず, まず, 脱窒や鉄還元などが活発に行われ る(表 1参照). 対象水域では, 水底近傍を除き水深全域 にわたり好気的状態にあった6月では, 水深が深いほじ $\mathrm{NO}_{3}{ }^{-}-\mathrm{N}$ は高濃度を示した. 好気的状態から嫌気的状態 へ移行した時点での $\mathrm{NO}_{3}{ }^{-}$が高濃度であるほど脱窒は長期 化する. その結果として, 硫酸還元やメタン生成よりも高い 酸化還元電位を持つ脱窒がORPの低下を遅くさせると推 察できる.この点を鑑みると, $\mathrm{NO}_{3}{ }^{-}$が低濃度の $5 \mathrm{~m} て ゙ \mu_{E}$ の
值は大きく, 一方, 高濃度の $7 \mathrm{~m}$ ではORPの低下速度は遅 い結果となったと考えられる.このように, ORPに対する多 様な環境要因の影響の強さは $E_{\min }$ や $\mu_{E}$ に反映されること が示唆されることから, 化学的・水質学的視点から両パラメ 一夕を詳細に検討することが今後の課題である.その一つ として, 本研究では対象項目外であった $\mathrm{Fe}^{3+}$ との関連性が 挙げられる。

\section{3 還元的条件下での窒素・リン・硫黄の動態}

還元的条件下での水質環境の動態特性に着目するため に, 多点定期観測期間中にORPが負に転じた $5 \mathrm{~m}$ 以深を 対象に, ORPに対する $\mathrm{NO}_{3}{ }^{-}-\mathrm{N}, \mathrm{NH}_{4}{ }^{+}-\mathrm{N}, \mathrm{PO}_{4}{ }^{3-}-\mathrm{P}$, 硫化 物および $\mathrm{SO}_{4}{ }^{2-}$ 応答性を水深ごとに調べた. その結果を 図 8 に示す. 同図は, 無酸素条件下におけるORPと水質 の関係であり, $\mathrm{NH}_{4}{ }^{+}-\mathrm{N}, \mathrm{PO}_{4}{ }^{3-}-\mathrm{P}$, 硫化物の各濃度は対 数軸で図示している. 図 8 より, ORP $<0 \mathrm{mV}$ の還元的条 件下で, 電位の低下に対して $\mathrm{NH}_{4}{ }^{+}-\mathrm{N}, \mathrm{PO}_{4}{ }^{3-}-\mathrm{P}$, 硫化物 の各濃度は指数関数的に増加し, $\mathrm{SO}_{4}{ }^{2-}$ は減少する傾向 が窺えるものの，その関係性は明確ではない。むしろ， $\mathrm{NH}_{4}{ }^{+}-\mathrm{N}, \mathrm{PO}_{4}{ }^{3-}-\mathrm{P}$, 硫化物は, ORPが-200mVを下回ると 急激に増加し, おおよそ-250mVに対してこれらの濃度は 広範囲に渡ってプロットされた。また，ORP $<-200 \mathrm{mV}$ $\mathrm{SO}_{4}{ }^{2-}$ は減少傾向を示し, さらに同範囲で $\mathrm{NO}_{3}{ }^{-}-\mathrm{N}$ は概ね ゼロであった. 以上から, 還元的条件下での窒素・リン・硫 黄の無機化合物イオンの濃度変化をORPのみの関数とし て捉えることは難しいといえる. ここで, ORP <-200 mVで $\mathrm{NO}_{3}{ }^{-}-\mathrm{N}$ がほぼ消滅したことから, 脱窒の完了によって還 元半反応は, より電位の低い鉄還元や硫酸還元に移行し たと考えられる. 換言すると, ORP $=-200 \mathrm{mV}$ は, 還元的 条件による $\mathrm{NH}_{4}{ }^{+}-\mathrm{N}, \mathrm{PO}_{4}{ }^{3-}-\mathrm{P}$, 硫化物の増加過程の判断 材料であり, これらの濃度変化に対して閾值的な指標を意 味する. そこで, 還元的条件下では $\mathrm{NH}_{4}{ }^{+}-\mathrm{N}, \mathrm{PO}_{4}{ }^{3-}-\mathrm{P}$, 硫
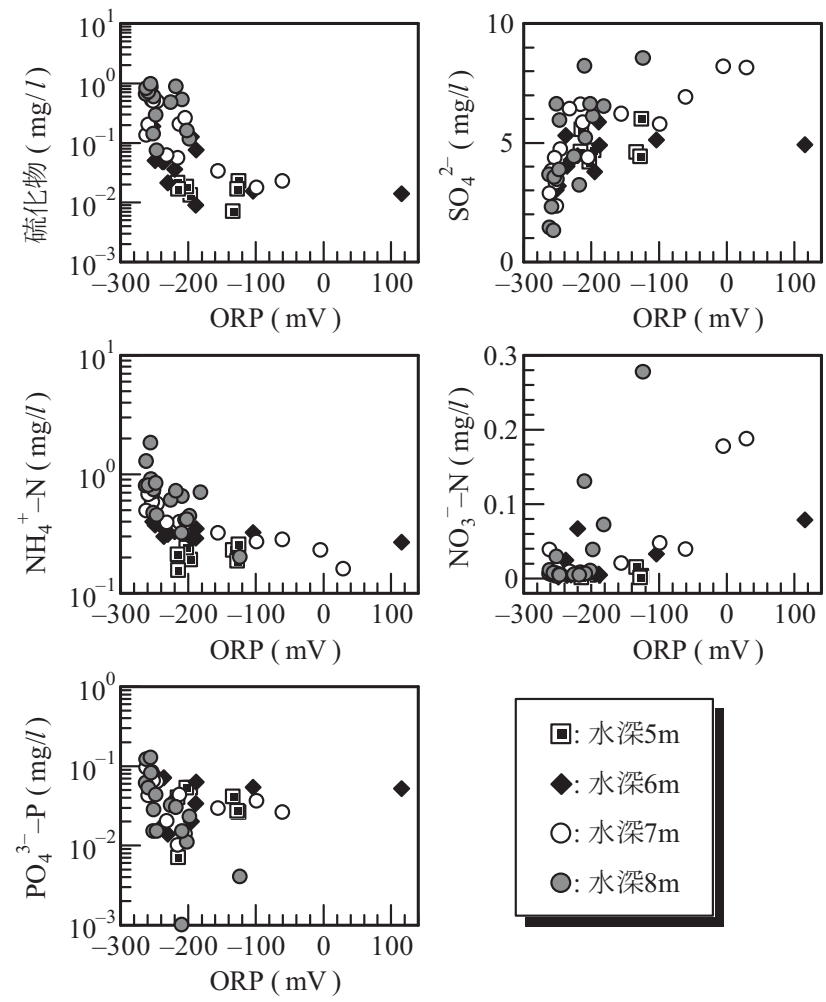

図 8:5m以深での無酸素条件下におけるORPに 対する窒素・リン・硫黄化合物の濃度変化 
化物はORP $<-200 \mathrm{mV}$ の状態の時間経過とともに増加し, 一方, $\mathrm{SO}_{4}{ }^{2-}$ は減少傾向に転じると考えた. なお, 3.1節で 述べたように, 観測期間を通じて $5 \mathrm{~m}$ 以深は光強度ゼロの 条件にあつた。つまり, 上記の考えでは, 光合成量は皆無 であるという点で, 栄養塩の変化に対する植物プランクトン の影響は極めて小さいことも踏まえている.

図 9は, 硫化物, $\mathrm{SO}_{4}{ }^{2-}, \mathrm{PO}_{4}{ }^{3-}-\mathrm{P}, \mathrm{NH}_{4}{ }^{+}-\mathrm{N}, \mathrm{NO}_{3}{ }^{-}-\mathrm{N}$, ORP, DOの経時変化を水深ごとにまとめたものであり, 各 水深で決定されるORP $<-200 \mathrm{mV}$ となった日を時間軸 $t^{\prime}$ の原点とした。同図より, $\mathrm{SO}_{4}{ }^{2-}$ が最小值をとる日まで, $\mathrm{NH}_{4}{ }^{+}-\mathrm{N}, \mathrm{PO}_{4}{ }^{3-}-\mathrm{P}$, 硫化物はいずれも時間 $t^{\prime}$ の経過に対

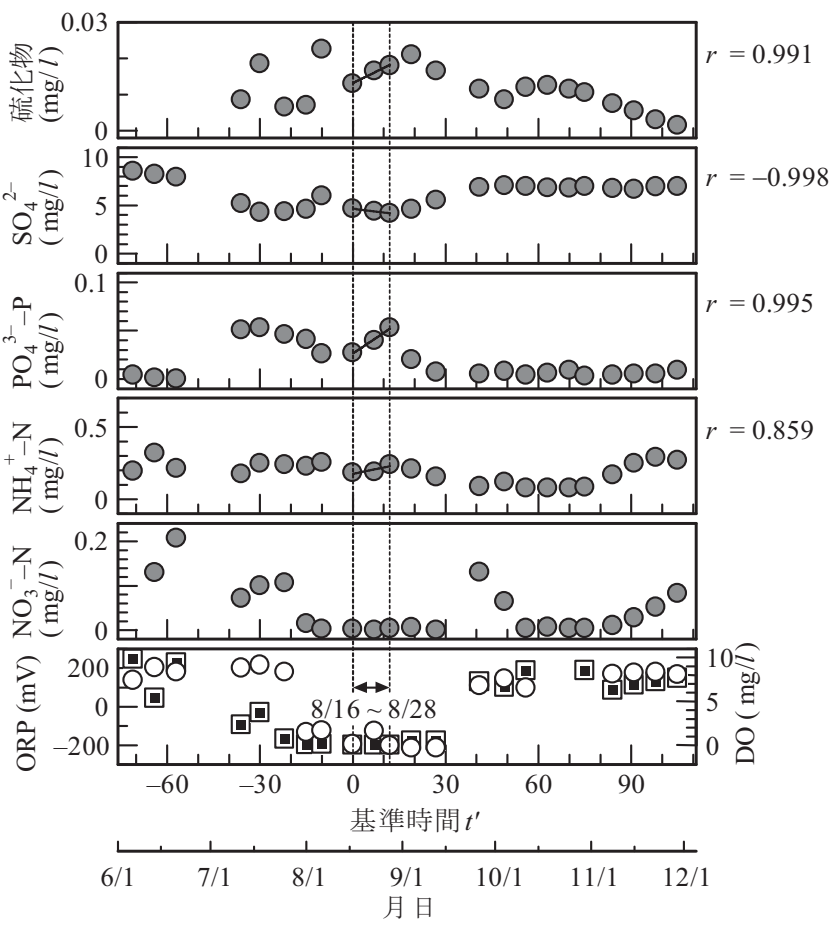

(1) 水深 $5 \mathrm{~m}$ ( 口:DO, O: ORP, O:室内分析項目)

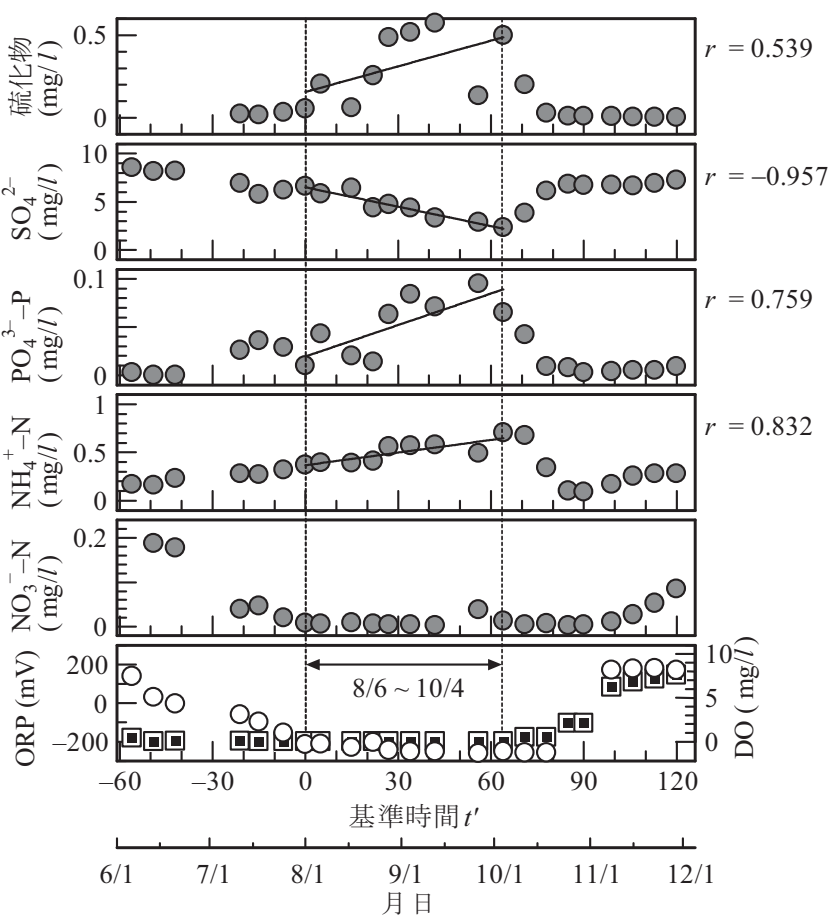

(3) 水深7m( 口:DO, O:ORP, O:室内分析項目)
して線形的に増加することが見出せ，また $\mathrm{NO}_{3}{ }^{-}-\mathrm{N}$ ほほぼ ゼロであることを確認できる. 特記するべき点は, 水深 $5 \mathrm{~m}$ では9月4日以降に, 水深6mでは9月 12 日に, 水深 $7 \mathrm{~m}, 8 \mathrm{~m}$ の両点では10月 4 日以降に, ORP $<-200 \mathrm{mV}$ の状態であ るにも関わらず $\mathrm{NH}_{4}{ }^{+}-\mathrm{N}, \mathrm{PO}_{4}{ }^{3-}-\mathrm{P}$, 硫化物は減少したこと である.このときのDOは0.2〜0.5mg/l僅かながら存在し， 硫化物の酸化に起因する $\mathrm{SO}_{4}{ }^{2-}$ の増加も確認できる. 例え ば, 図 1に示した10月4日のDOとORPの鉛直分布に着目 すると, 水深 $6 \mathrm{~m} は \mathrm{ORP}<0, \mathrm{DO}>0$ の状態にあった。この 測定点の直上にあたる水深 $5.5 \mathrm{~m}$ で混合層が到達し, 無 酸素化が解消されたことから，水塊の鉛直混合の影響が
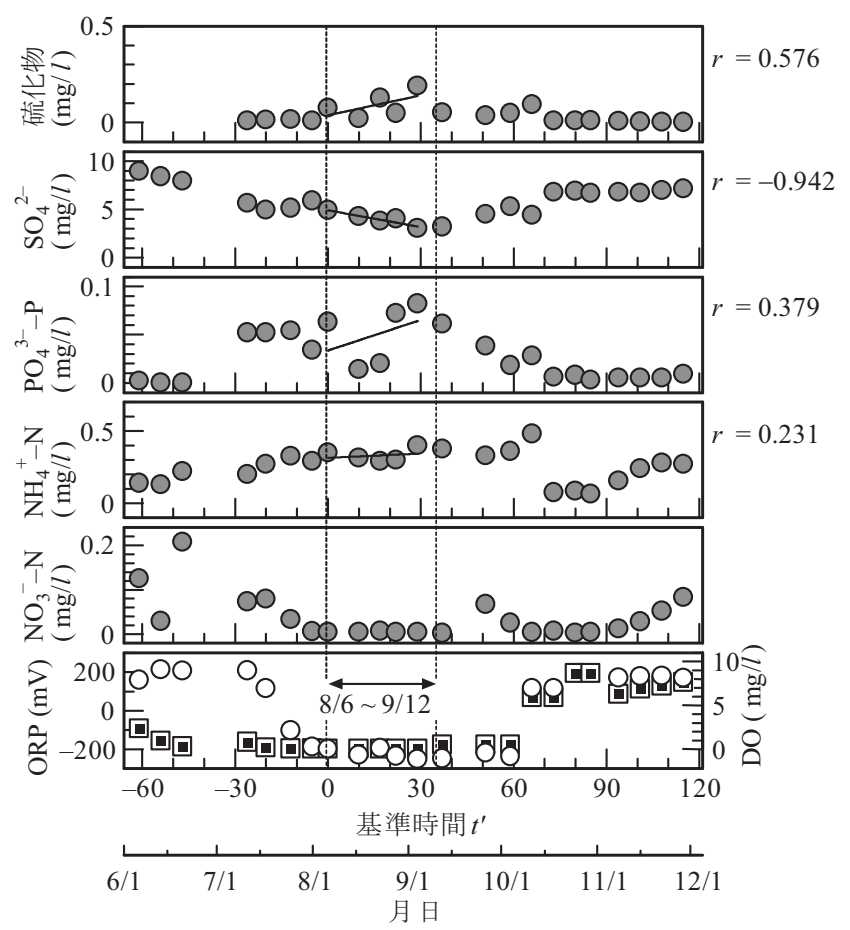

(2) 水深6m（ 回:DO, O: ORP, O:室内分析項目 )

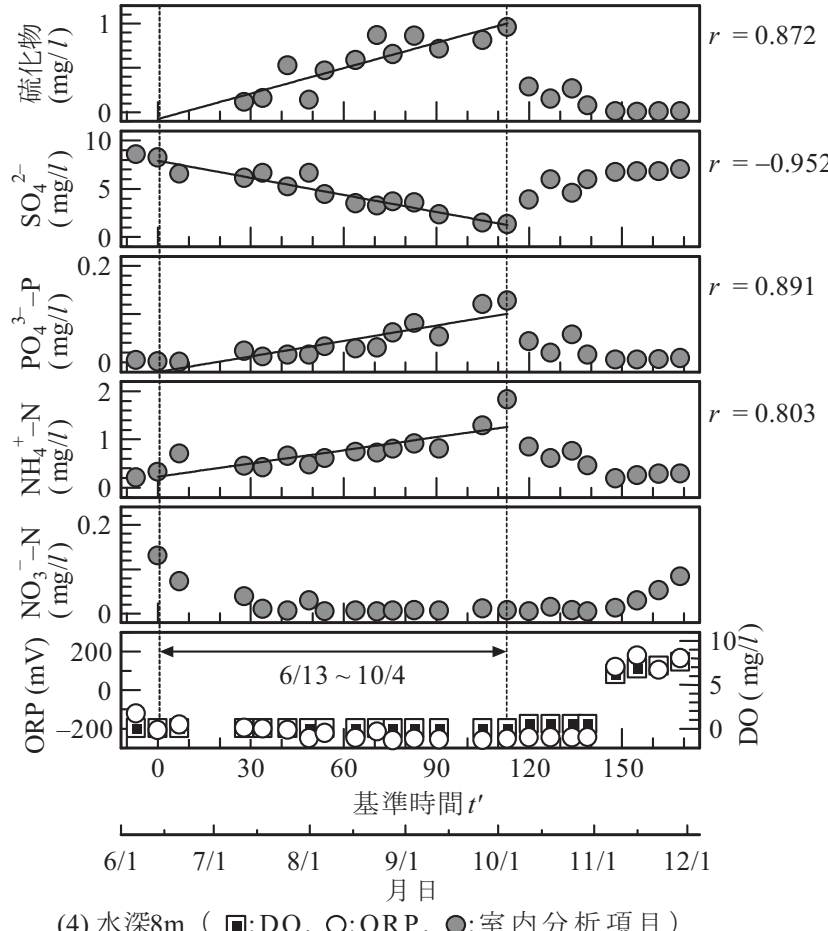

図 9: 水深 $5 \mathrm{~m} \sim 8 \mathrm{~m}$ における窒素・少・硫黄の無機化合物イオンの経時変化と回帰分析 
水深6mにまで及び, 極少量のDOが供給されたと推察でき る.つまり, 直上までの混合層の発達によって $\mathrm{DO}>0$ とな り, ORPに変化を与えるほどの影響はないものの, 僅かな $\mathrm{DO}$ の存在により $\mathrm{NH}_{4}{ }^{+}-\mathrm{N}, \mathrm{PO}_{4}{ }^{3-}-\mathrm{P}$, 硫化物は減少に, $\mathrm{SO}_{4}^{2-}$ は増加に転じたと考えられる。

以上から, $\mathrm{ORP}<-200 \mathrm{mV}$ かつ $\mathrm{DO}=0 \mathrm{mg} /$ 苂維持さ れた期間を対象に, $\mathrm{NH}_{4}{ }^{+}-\mathrm{N}, \mathrm{PO}_{4}{ }^{3-}-\mathrm{P}$, 硫化物, $\mathrm{SO}_{4}{ }^{2-}$ の 経時変化を $t^{\prime}$ に関する線形回帰モデルで表した. 図 9中 の直線はその結果であり, 相関係数を合わせて図中に示 寸. 同図より, 水深が深いほど良好な回帰式が得られたこ 之が分かる. 水深 $6 \mathrm{~m}^{-} \mathrm{PO}_{4}{ }^{3-}-\mathrm{P}$, 硫化物, $\mathrm{NH}_{4}{ }^{+}-\mathrm{N}$ の観測 值にややばらつきがあり, 相関係数の值も小さな結果を示 したものの, 水深に関係な $\left\langle\mathrm{NH}_{4}{ }^{+}-\mathrm{N} や \mathrm{PO}_{4}{ }^{3-}-\mathrm{P}\right.$ の栄養塩, ならびに硫化物と $\mathrm{SO}_{4}{ }^{2-}$ の硫黄化合物は, $\mathrm{ORP}<-200 \mathrm{mV}$ となる還元状態の経過日数を説明変数とする線形回帰式 によりモデル化できると考えてよい.ただし，水深 $5,6 \mathrm{~m} に$ ついては対象データが少ないため, データ数をより増やし た上での検討が今後の課題である.いずれの水深におい て, $\mathrm{NO}_{3}{ }^{-}-\mathrm{N} か ゙ \mathrm{ORP}$ の低下とともに減少したこと, またORP が概ね $-200 \mathrm{mV}$ に至った時点でその濃度がゼロとなった こと, それ以降に硫化物が増加し始めたことが確認された。 硫酸還元菌が $\mathrm{NO}_{3}$-の存在しない条件下で活性を持つこと から (栗原, 1988), $t^{\prime}=0$ のもつ化学的意味は, 嫌気的条 件下のもと脱窒が完了し, 次の還元反応である鉄還元や 硫酸還元に移行した時点として考えられる.

\section{4 おわりに}

本研究では, 脱窒や硫酸還元などの嫌気的有機物分解 の発生メカニズムの究明に関する基礎的研究しして, 有機 污濁が顕在化した貯水池を対象に水質モニタリングを実 施し, 嫌気的・還元的条件下にあるORP, および $\mathrm{NH}_{4}{ }^{+}-\mathrm{N}$, $\mathrm{PO}_{4}{ }^{3-}-\mathrm{P}$, 硫化物, $\mathrm{SO}_{4}{ }^{2-}$ の経時変化を評価しうる回帰モデ ルを検討した. 本研究の結果を以下の通りまとめる.

(1) 嫌気的条件下でのORPの動態は, 無酸素継続日数 を時間軸と寸るロジスティック曲線を用いてモデル化 ができる. モデルパラメータの一つであるORPの低下 速度は成層化初期の $\mathrm{NO}_{3}{ }^{-}$濃度に依存し, 高濃度で あるほど脱窒が長期化する結果, ORPは緩やかに低 下寸る.

(2) $\mathrm{ORP}<-200 \mathrm{mV}$ かつ $\mathrm{DO}=0 \mathrm{mg} /$ /が維持された状態 の経過日数を説明変数とする線形回帰モデルにより, 還元的条件下に起因古る $\mathrm{NH}_{4}{ }^{+}-\mathrm{N}, \mathrm{PO}_{4}{ }^{3-}-\mathrm{P}$, 硫化 物の経時的な増加過程, ならびに $\mathrm{SO}_{4}{ }^{2-}$ の減少過程 を表すことができる. 寸なわち, 脱窒の還元反応が完 了し, より電位の低い鉄還元や硫酸還元に移行した 条件下で, $\mathrm{NH}_{4}{ }^{+}-\mathrm{N}, \mathrm{PO}_{4}{ }^{3-}-\mathrm{P}$, 硫化物は時間経過に 比例して増加する.

最後に, 上記 2 点の結果の意義について水環境解析の 視点からまとめる. 窒素・リンや溶存酸素などを指標とする 水環境の動態解析には, 一般に, 生態系モデルに代表さ れる水質予測モデルが用いられる(例えば，原田ら， 2009). しかしながら, 同モデルは多くの決定すべきパラメ 一夕を含むため, 実水域一の適用は決して容易ではない. 一方, 閉鎖性水域における水温鉛直構造の季節変化に 関する数值解析は比較的容易である. 原田ら(2007)は, 鉛直1次元水温拡散モデルを用いて, 富栄養湖における
水温成層の形成・破壊過程を精度よく予測でき, この計算 結果から貧酸素・無酸素化の発生や解消のタイミングを推 定できることを示した.このような数值シミュレーションを利 用して, 本研究で定義した無酸素継続日数を算定でき, こ の算定值を用いて嫌気的条件下でのORPの経時变化を 式(2)より予測することができる. ついで， ORP $<-200 \mathrm{mV}$ の状態の経過日数を説明変数と寸る線形回帰モデルによ り $\mathrm{NH}_{4}{ }^{+}-\mathrm{N}, \mathrm{PO}_{4}{ }^{3-}-\mathrm{P}, \mathrm{SO}_{4}{ }^{2-}$, 硫化物の動態も推測できる. すなわち, 図 7,9のような回帰モデルを利用することで, 複雑な生物化学的なプロセスを数学的にモデル化するこ 々なく栄養塩や硫黄化合物の動態の簡便的な推定・予測 が可能となる. 今後, 本研究のような水質モニタリング結果 を蓄積し, 式(2)のパラメータや窒素・リン・硫黄の無機化合 物イオンの動態に関わるORPの閾值について詳細な知見 を得ることで, 実水域における嫌気的有機物分解の発生义 カニズムに繋がると考える.

謝辞: 本研究の一部は, 日本学術振興会科学研究費補助金・若 手研究(B) (課題番号23780249)ならびに平成24～26年度日本 学術振興会研究拠点形成事業(B.アジア・アフリカ学術基盤形 成型, 東南アジア新興国流域圈における水環境統合管理ツー ルに関する研究拠点形成と人材育成)を受けた. ここに記して感 謝の意を表する.

\section{引用文献}

[1] 安部喜也・半谷高久翻訳 (1976): 一般水質化学〈下 $\rangle$, 共立出版, p.299.

[2] 有田正光編 (1998): 水圈の環境, 東京電機大学出版局, pp.20-23.

［3］原田昌佳・齋幸治・三島雅子・吉田勲・平松和昭・森牧人 (2007): 湖山池の密度成層の形成過程と破壊過程につ いて, 農業農村工学会論文集, 75(5), pp.107-115.

[4] 原田昌佳・平松和昭・齋藤孝・森牧人・丸居篤 (2009): 寡少な水中光環境下にある富栄養化水域の水質の動態 特性, 雨水資源化システム学会誌, 14(2), pp.87-96.

[5] 今井章雄 (2004): 水環境におけるフミン物質の特徵と役 割, 水環境学会誌, 27(2), pp.76-81.

[6] 栗原康編 (1988): 河口・沿岸域の生態学とエコテクノロジ 一, 東海大学出版会, pp.32-42.

[7] 武藤暢夫 - 金甲守 (1986): 都市河川等における水, 底泥 の酸化還元電位の測定方法と測定值の評価, 水質污濁 研究, 9(2), pp.104-112.

[8］永田俊・熊谷道夫・吉山浩平編 (2012): 温暖化の湖沼学, 京都大学学術出版会, pp.150-161.

[9] 中村幹雄・品川明・戸田顕史 (1997): ヤマトシジミの硫化 水素而性, 水産増殖, 45(1), pp.17-24.

[10] 寒川喜三郎・日色和夫 (1996): 最新の底質分析と化学 動態, 技報堂出版, pp.77-116.

[11] 武田育郎 (2001): 水と水質環境の基礎知識, オーム社, pp.23-74.

[12] 山室真澄・石飛裕・ 中田喜三郎・中村由行 (2013): 貧酸 素水塊一現状と対策, 生物研究社, pp.1-26.

[13] 吉村侑一郎・原田昌佳・平松和昭・丸居篤 (2010): 伊都 キャンパス内 5 号調整池における水環境特性の定量化, 九州大学大学院農学研究院学芸雑誌, 65(2), pp. 91-105.

この論文の公開の質疑または討議は2015年6月30日 まで受付けます。 